\title{
Suzhou's Building of a Paradigm in Global Energy Transtion-Driven Urban Development: The Idea and its Background
}

\author{
Lin-Yu WANG ${ }^{1, a}$, Qiang SUN ${ }^{1, b,{ }^{*}}$, Rui-Xin $\mathrm{CHEN}^{1, \mathrm{c}}$ and Wei-Yang $\mathrm{LI}^{1, \mathrm{~d}}$ \\ ${ }^{1}$ State Grid Energy Research Institute, Future Technology Park, Changping, Beijing, China \\ awanglinyu@sgeri.sgcc.com.cn, bsunqiang@sgeri.sgcc.com.cn, cchenruixin@sgeri.sgcc.com.cn
}

Keywords: Energy Transition, Paradigm, Energy Consumption, Urban.

\begin{abstract}
Over the past centuries, the massive consumption of coal, oil and other traditional fossil energy has posed threats and challenges to sustainable development due to the emission of plenty of green-house gas, especially cities in the world contribute $80 \%$ of it. To solve this problem, Suzhou, a modern and industrialized city in east China, has proposed an energy transtion plan with deep consideration of the urban comprehensive development. This paper introduces the idea and its background of the energy transition plan in Suzhou as an example for the sustainable development with the energy transition for all the other cities. The reasons why Suzhou is a suitable candidate is expressed, the transition plan is listed with deep consideration of the background of Suzhou.
\end{abstract}

\section{Introduction}

Energy is an important material base of the social and economic development. It is also the strong driving force for changes in human civilization. As has been mentioned in many literatures [1,2,3], energy is closely associated with the national economy as well as people's livelihood and human well-being. Over the past centuries, fossil energy is the major energy resource, and with the economic bloster and social development, more and more fossil energy are exploited and consumed, in 2015, the world's primary energy consumption reached 18.78 billion tons of standard coal, fossil energy accounted for $85.9 \%$ of the total energy consumption [2], which hit a record high, overdevelopment of conventional fossil energy resulted in a host of problems, such as insufficient resources, environmental pollution, and climate change, which are threatening human existence and sustainable development. Countries all over the world now share a strategic goal to expedite the development of a safe, reliable, economical, efficient, clean, and environment-friendly modern energy supply system by capitalizing on a new round of energy transition.

Since 2007, the world's urban population has exceeded the rural population. Cities are the major consumer of global energy, thus playing a decisive role in the global energy pattern. According to a report from International Energy Agency (IEA) [3], in 2015, people living in the urban areas accounted for over a half of the total population, contributing to approximately $80 \%$ of the GDP and consumed $2 / 3$ of the primary energy while resulting in $70 \%$ of the carbon emission. In the near future, people living in the urban areas is still expected to increase. Therefore, the cities shall be the pioneer in the transition to the sustainable development of global energy.

Although the city occupies such an important place in energy consumption, it has been underestimated in the entire energy system for a long time. Today's urban infrastructure, especially its energy systems, does not adequately prepare for future sustainable urban development and sustainable energy development. In order to keep a sustainable development for the city and to make demonstration for the energy transitions in other cities in China, in 2016, during the second international forum on energy transitions, Suzhou, together with State Grid Jiangsu electric power company, with intelligent support from State Grid Energy Research Institite (SGERI), proposed the first plan for energy transition in Suzhou.

The left of the paper are organized in the following sequence: the second section introduces the connotation of the energy transition plan, why Suzhou is chosen is explained in section three, in section four the framework of the plan are given, the conclusion is presented in section five. 


\section{Connotation of the Paradigm in Global Energy Transition}

Many energy transition plans appeared in the world have taken the revoluation of the energy as the major objective, thus all the follow-up projects are limited to think energy in the energy system of various types, a typical example for this is the the marquee project in Masdar city of the United Arab Emirates' (UAE) [4,5], when it was first conceived a decade ago, was intended to revolutionise thinking about cities and the built environment . Now the world's first planned sustainable city could well be the world's first green ghost town. Managers have given up on the original goal of building the world's first planned zero-carbon city. The reasons why this project is failure may be a lot, however, a key factor is that all the plan did not consider the status and situation of the development of the city carefully, therefore lack of capital, lack of citizens, lack of communal facilities, all the consequence of a failed top-level design made the goal of zero-carbon city as castles in the air.

Suzhou's building of a paradigm in global energy transtion-driven urban development, which different with all the other energy transition plans, is with the consideration of the comprehensive development of the city, and is totally reconciled with the development of the city.

Paradigm cities in Global energy transition refer to those pioneer cities worldwide that focus on specific or extensive challenges concerning energy transitions and based on their own situations, and create typical, leading and demonstrative practice of success. These successful practices should provide notable values to the development of economics, society and environment. These pioneering cities should be able to provide effective implications for energy-driven urban development for other countries and cities.

"Paradigm" means that the energy transition practices of a specific city are typical, leading and demonstrative. "Typical” means that the energy transition challenges overcome by a specific city isuniversal and extensive. "Leading" means that the energy transition measures of a specific city are advanced and pioneering. "Demonstrative” means that the energy transition experience of a specific city is duplicable and promotable.

\section{Characteristics Analysis of Suzhou as Candidate}

\section{Suzhou as a City}

Suzhou is an industrial city with a population of more than 10 millions; it can be seen as an epitome of the Chinese economy and energy development. Suzhou's GDP growth rate keeps in line with that of China as it is in the midst of moving from rapid growth to medium-to-high growth, as can be seen from Fig.1. The Changes of industry structure in Suzhou follow those of China. Manufacturing serves as Suzhou's core industry sector, and industry enjoys a great share. In 2016, the tertiary industry contributes $51.4 \%$ of Suzhou's GDP [6], for the first time in the last 40 years it is higher than the second industry. Energy consumption growth rate in Suzhou keeps pace with that of China, fluctuating with a downward trend in recent years.

The structure of energy consumption featuring coal's dominance in Suzhou is highly similar to that of China. As been shown in Fig.2, in 2015, coal consumption in Suzhou accounts for over 66\% of the city's total, while during the same period, coal consumption in China accounts for $64 \%$ of the national total.

Since the tendency and status of economy and energy consumption are similar, the pathways and approaches for energy transition-driven economy and society development in Suzhou are typical, therefore the experience obtained in Suzhou are duplicable. 

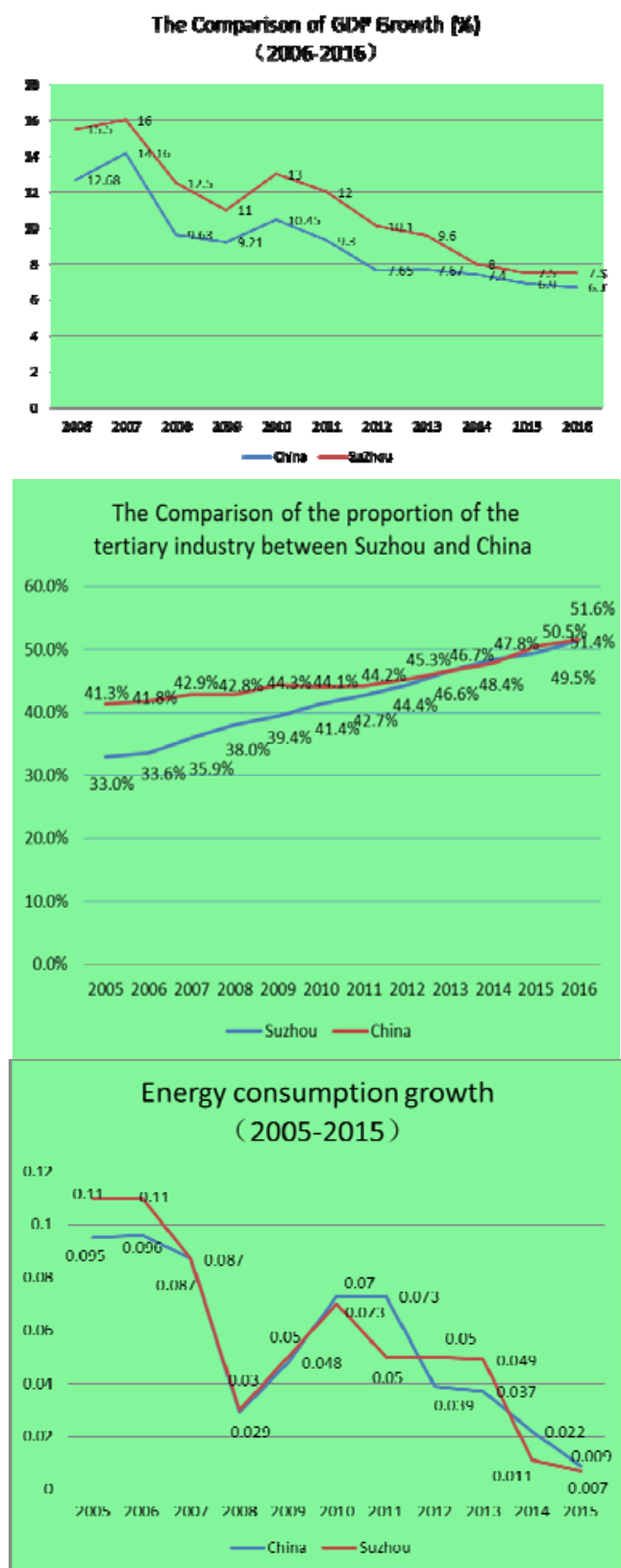

Fig. 1 the comparison between Suzhou and China (a) GDP (b) proportion of the tertiary industry (c) energy consumption

\section{Suzhou's Energy Pattern}

With in about 60 years, Suzhou has been from a backward city with weak industrial base into a modern industrial city, which could be hundreds of year experience for foreign cities. This short period implies that the energy supply and consumption may not match with the society well. Therefore it is found that Suzhou synthetically reflects the modern urban energy form.

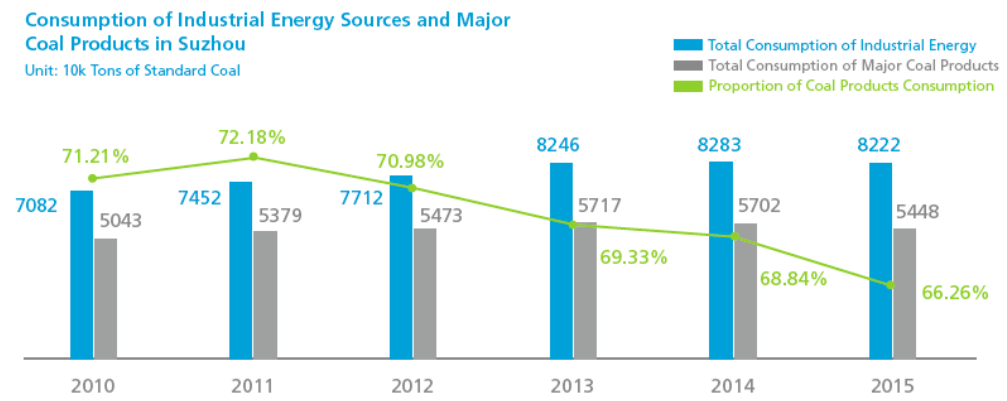

Fig.2 total energy and major coal products consumption in Suzhou 
Suzhou boasts a complete energy-supplying system with both electricity and all types of fossil fuels, and consumes more electricity generated out of the city. The voltage level across the city ranges from $1,000 \mathrm{kV}$ UHV AC and $\pm 800 \mathrm{kV}$ UHV DC to the voltage supplied to residential customers. The city is equipped with major interconnected power system and micro-grid system, with types of energy, covering fossil fuels, wind energy, solar power, geothermal energy, biomass energy, and stored energy. It possesses a tiered energy-supplying system with supplying patterns covering "low consumption and high efficiency "high consumption and high efficiency" and "low consumption and low efficiency", the energy consumption of some typical products has reached leading level, the overall energy consumption of Suzhou remains high due to unbalanced industrial structure. Compared with developed countries, it still has a very long journey to go and a remarkable space for energy saving, which is shown in Fig.3. Energy supply generally meets the city's demand, but doesn't keep in line with the city's growth pattern. Fractured divisions between energy management areas remain severe, thus supply and demand in energy are somewhat curbed.

Suzhou's energy transition practices can serve as an important sample for cities at home and abroad.

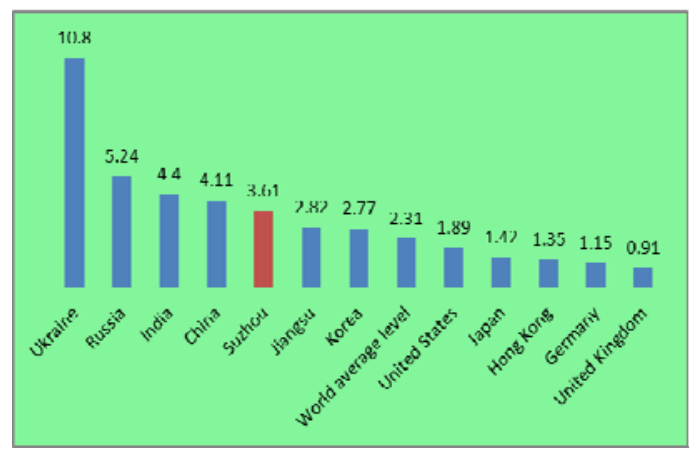

Fig.3 Energy consumption intensities of some countires and regions 2014 (tons of SCE/10k USD)

\section{Suzhou's Experience as Pilot}

Suzhou has rich experience in pilot projects. For example, it is one of the first national smart city pilots, one of the first national cydic economy demonstration cities, one of the first ecological industry demonstration parks, etc... Suzhou is a policy-based pilot zone, vanguard zone of technology promotion, and demonstrating zone of project construction. Suzhou has gained rich experience in piloting, fusion and innovation of policy, technology, and program. This pilot experience can give rise to Suzhou's push for global paradigm in energy transition.

\section{Framework of the Energy Transition Plan}

The framework of the plan, as mentioned before, is composed in five parts, the first four parts concerns the objective: the development of the city, the pathway: global energy interconnection, the fundamental: a sustainable urban energy system, the supporting technologies: a sustainable urban energy system, the final part is on the spread of the sucessful experience: brand building. 
Tab.1 the main contents of the energy transition plan and its background

\begin{tabular}{|c|c|c|c|}
\hline $\begin{array}{l}\text { Energy transition } \\
\text { blanks }\end{array}$ & Advantages & $\begin{array}{l}\text { Possible creative } \\
\text { Practices }\end{array}$ & $\begin{array}{c}\text { Orientation of the } \\
\text { building of a paradigm }\end{array}$ \\
\hline $\begin{array}{c}\text { The way that energy } \\
\text { drives the development } \\
\text { of the city }\end{array}$ & $\begin{array}{l}\text { Suzhou bears the sense } \\
\text { of urgency for energy } \\
\text { transition driven urban } \\
\text { development }\end{array}$ & $\begin{array}{c}\text { Explore innovative } \\
\text { pathways for } \\
\text { comprehensive } \\
\text { development of energy } \\
\text { transition driven cities }\end{array}$ & $\begin{array}{l}\text { Becoming a model of } \\
\text { leading the } \\
\text { transformation and } \\
\text { upgrading of } \\
\text { energy-driven urban } \\
\text { development pattern }\end{array}$ \\
\hline $\begin{array}{c}\text { Global energy } \\
\text { interconnection } \\
\text { initiative requires } \\
\text { urgent implementation }\end{array}$ & $\begin{array}{l}\text { Key technologies for } \\
\text { the implementation of } \\
\text { the Global Energy } \\
\text { Interconnection } \\
\text { strategy has been } \\
\text { gathered in Suzhou }\end{array}$ & $\begin{array}{c}\text { Explore innovative } \\
\text { pathways for } \\
\text { comprehensive } \\
\text { development of energy } \\
\text { transition driven cities }\end{array}$ & $\begin{array}{l}\text { Becoming a model of } \\
\text { leading the } \\
\text { implementation of the } \\
\text { Global Energy } \\
\text { Interconnection } \\
\text { Strategic vision }\end{array}$ \\
\hline $\begin{array}{l}\text { Sustainable urban } \\
\text { energy supply system } \\
\text { need to be explored }\end{array}$ & $\begin{array}{l}\text { Suzhou is a typical } \\
\text { sample of modern } \\
\text { urban energy system }\end{array}$ & $\begin{array}{c}\text { Create successful } \\
\text { experience in } \\
\text { sustainable urban } \\
\text { energy supply system }\end{array}$ & $\begin{array}{l}\text { Becoming a model of } \\
\text { leading the building of } \\
\text { a sustainable urban } \\
\text { energy system }\end{array}$ \\
\hline $\begin{array}{l}\text { Achievements in } \\
\text { global energy } \\
\text { transitions require } \\
\text { demonstration, fusion } \\
\text { and promotion. }\end{array}$ & $\begin{array}{c}\text { Series of } \\
\text { groundbreaking, } \\
\text { leading and pilot } \\
\text { projects and programs } \\
\text { gather in Suzhou }\end{array}$ & $\begin{array}{l}\text { Promote the priory } \\
\text { implementation, } \\
\text { integration and } \\
\text { innovation of global } \\
\text { energy transition } \\
\text { achievements }\end{array}$ & $\begin{array}{l}\text { Becoming a model in } \\
\text { the integration and } \\
\text { innovation of global } \\
\text { energy transition } \\
\text { achievements }\end{array}$ \\
\hline \multicolumn{3}{|c|}{$\begin{array}{l}\text { strengthen quality demonstration and promotion of a paradigm on the basis } \\
\text { of the "Four Guides" in the building process }\end{array}$} & $\begin{array}{l}\text { Becoming a model of } \\
\text { leading the } \\
\text { demonstrative effect } \\
\text { and international } \\
\text { influence of energy } \\
\text { transitions }\end{array}$ \\
\hline
\end{tabular}

\section{Conclusions}

This paper introduces the background and the framework of the energy transition plan of Suzhou. The gestation of Suzhou's building of a paradigm in global energy transition-driven urban development is based on the realization that energy transition is necessary and must be performed under the consideration of the comprehensive development of the city. Suzhou has natural advantages and was chosen carefully, the sucessful experience obtained from Suzhou can be further duplicated by other cities since Suzhou is an epitome of the Chinese economy and energy development, and is full of varieties of energy form.

\section{References}

[1] Zhenya Liu, Global Energy Interconnection, first ed., Elsevier, New York, 2016.

[2] BP Statistical Review of world energy 2016, information on http://www.bp.com

[3] IEA, Energy Technology Perspectives 2016: Towards sustainable urban energy systems. (Chinese vesion)

[4] Tasneem Abbasi, M.Premalatha, S.A.Abbasi, Masdar City: a zero carbon, aero waste myth, Current Science, Vol.102, No.1, 10 Jan. 2012 
[5] Masdar's zero-carbon dream could become world's first green ghost town, information on https://www.theguardian.com/environment/2016/feb/16/masdars-zero-carbon-dream-could-become -worlds-first-green-ghost-town

[6] Bulletin of statistics for national economic and social development of Suzhou, 2016, information on http://www.sztjj.gov.cn 